Krehl, W. A., Teply, L. J., Sarma, P. S. \& Elvehjem, C. A. (1945). Science, rox, 489.

Lampitt, L. H., Fuller, C. H. F. \& Goldenberg, N. (1947). F. Soc. chem. Ind., Lond., 66, 417.

Levy, J. \& Jacquot, R. (1948). C.R. Acad. Sci., Paris, 227, 37 I.

Luckey, T. D., Briggs, G. M. Jr., Moore, P. R., Elvehjem, C. A. \& Hart, E. B. (I945). F. biol. Chem. I6r, 395 .

Mawson, E. H. \& Thompson, S. Y. (1948). Biochem. F. 43, 2.

Mickelsen, O., Doeden, D. \& Keys, A. (1945). Fed. Proc. 4, 98.

Mitchell, H. K. \& Isbell, E. R. (I942), Univ. Texas Publ. no. 4237, p. 37.

Neilands, J. B. \& Strong, F. M. (1948). Arch. Biochem. r9, 287.

Olson, O. E., Fager, E. E. C., Burris, R. H. \& Elvehjem, C. A. (1948). F. biol. Chem. 174, 319.

Rabinowitz, J. C. \& Snell, E. E. (1947). Anal. Chem. 19, 277.

Roberts, E. C. \& Snell, E. E. (1946). F. biol. Chem. 163, 499.

Slater, E. C. \& Morell, D. B. (1946). Biochem. F. 40, 644.

Sreenivasan, A., Harper, A. E. \& Elvehjem, C. A. (1948). F. biol. Chem. 177, 117.

Teply, L. J. \& Elvehjem, C. A. (1945). F. biol. Chem. 157, 3 ०3.

\title{
The Heat of Combustion of the Tissues of Cattle in Relation to their Chemical Composition
}

\author{
By K. L. BLAXTER AND J. A. F. ROOK \\ Hannah Dairy Research Institute, Kirkhill, Ayr
}

(Received 26 Fanuary 1952)

The estimation of energy retention by cattle from the results of simultaneous determinations of balances of carbon and of nitrogen is based on the assumption that fat and protein of constant chemical composition and calorific value are the only materials retained. The values employed for this purpose are usually those given by Armsby ( 1917 ):

Nitrogen retention $\times 6.25=$ protein retention; protein retention $\times 0.5254=$ carbon retention in protein; non-protein carbon retention $\times 1 \cdot 31=$ fat stored; protein stored (g) $\times 5 \cdot 7=$ calories stored as protein (Cal.); fat stored $(\mathrm{g}) \times 9 \cdot 5=$ calories stored as fat (Cal.).

The factors for protein are derived from Köhler's (I900-r) studies on the elementary composition of fat-free muscles of cattle. These results with those of other investigators are summarized in Table $\mathrm{I}$. Köhler's (r900-I) results with horse muscles, which are not included, gave lower values for nitrogen and for calories

Table I. Carbon and nitrogen content and the calorific value of fatand ash-free mammalian muscles

\begin{tabular}{|c|c|c|c|c|}
\hline \multirow[b]{2}{*}{ Investigator* } & \multirow[b]{2}{*}{ Date } & \multicolumn{3}{|c|}{ Composition on an ash-free basis } \\
\hline & & $\begin{array}{c}\text { Carbon } \\
(\%)\end{array}$ & $\begin{array}{c}\text { Nitrogen } \\
(\%)\end{array}$ & Cal. $/ \mathbf{k g}$ \\
\hline Rubner & $(1885)$ & $53 \cdot 4 \circ$ & 16.30 & $5656 \cdot 9$ \\
\hline Stohmann \& Langbein & $(189 \mathrm{I})$ & $52 \cdot 02$ & $16 \cdot 36$ & $5640 \cdot 9$ \\
\hline Argutinsky & $(1894)$ & $52 \cdot 33$ & $16 \cdot 15$ & - \\
\hline Köhler & $(1900-1)$ & 52.69 & 16.57 & $5700 \cdot 8$ \\
\hline
\end{tabular}


than those quoted in the table, and he attributed these low values to the presence of glycogen. The carbon content of fat used in the computation appears to be derived from the studies of Schulze \& Reineke (1867). These showed variations from $76 \cdot 50 \%$ carbon for beef fat to $77.62 \%$ carbon for human depot fat. The heat of combustion of fat, $9.5 \mathrm{Cal} . / \mathrm{g}$ appears to come from a compilation of early German results by Atwater (1895) and by Fries (1907), the values for cattle showing a variation of from 9357 to $9686 \mathrm{Cal} . / \mathrm{kg}$. Some of these analyses may be suspect. As Fries (1907) pointed out, very few of the published calorific values determined up to that time agreed within $\mathrm{r} \%$, even when crystalline simple organic compounds were analysed.

Apart from analytical errors in the determination of these factors for pure protein and fat, their use in calculation of energy storage within the animal body gives rise to two possible sources of error. Firstly, any variation in the composition of protein and of fat is not satisfactorily allowed for. In human beings, Cathcart \& Cuthbertson (193I) and Cuthbertson (1933) have shown that the calorific value of fat can vary from 8880 to $9523 \mathrm{Cal} / \mathrm{kg}$ depending on the source of the material. Such variations are very significant in terms of energy storage. Secondly, errors arise as a result of the assumption that energy is stored only as fat or protein. It is generally believed that the main interpretational error attached to the computation of energy balance from the carbon and nitrogen balance is due to the assumption that all the nonprotein carbon represents fat. One gram carbon stored as glycogen would represent approximately $9 \cdot 2 \mathrm{Cal}$. and as fat $12 \cdot 4 \mathrm{Cal}$. The maximum overestimation therefore would be $30 \%$. In the growing animal it is doubtful whether glycogen represents more than $2 \%$ of the body-weight and the actual error is probably an overestimation of energy storage by $0.6 \%$. A further interpretational error, which does not appear to have been considered, is the possibility that, in certain instances, phospholipin may account for a large fraction of the lipid stored. No published figures are available for the calorific value of phospholipins which, since they contain nitrogen, would be estimated partly as protein and partly as fat.

To provide further information on the accuracy of prediction of energy storage from Armsby's (1917) factors, an examination of the carbon and nitrogen contents and energy value of body tissues of cattle was undertaken. Comparable analyses of isolated tissue components were also made, and the results used to illustrate the possibility of error.

\section{Materials}

\section{METHODS}

Samples of nine muscles, of five brains and of five livers were analysed. They were obtained from freshly killed animals and were dried at $100^{\circ}$ before analysis. Five samples of depot fat were dried in vacuo over calcium chloride. Details of the preparation of brain phospholipins, liver glycogen and myosin are given later.

\section{Chemical methods}

Nitrogen was determined by macro-Kjeldahl analysis. Carbon was determined by combustion of the sample in a stream of oxygen in a tube packed with copper oxide and lead chromate, using the precautions listed by Pregl (1924). The carbon dioxide 
was absorbed in solid sodium hydroxide dispersed with pumice stone. Ash was determined by incineration at $55^{\circ}$.

\section{Calorimetric methods}

Calorific values were determined in a standard pattern of bomb calorimeter. The water equivalent of the bomb was determined by use of benzoic acid (thermochemical standard grade, British Drug Houses Ltd.). The Regnault-Pfaundler cooling correction was used, and a correction was inserted for the heats of formation and of solution of the higher oxides of nitrogen. Sulphur was determined by analysis of the washings of the bomb. No allowance was made for possible impurities in the oxygen supply, but care was taken to make all determinations at the same oxygen pressure. The increase in temperature of the calorimeter was measured by a thermistor circuit calibrated to give a range from 15 to $20^{\circ}$, and to read to the nearest $0.00 \mathrm{I}^{\circ}$. Details of this instrument and instructions for its calibration and use are given by Beakley (I95I), to whom we are indebted for assistance. The thermistor circuit was calibrated using a long-stem mercury-in-glass thermometer with an N.P.L. certificate, reading to the nearest $0.01^{\circ}$, over the range $15^{-2}-20^{\circ}$.

\section{Preparation of myosin, fat, phospholipins and glycogen}

Myosin. Muscle, freed from visible fat, was homogenized in a $\mathrm{KCl}-\mathrm{NaHCO}_{3}$ buffer, and the protein in the extract was precipitated by dilution in 20 vol. water (Edsall, 1930). The precipitate was redissolved in the buffer and again precipitated by dilution. It was finally dried with acetone and then by desiccation in vacuo over $\mathrm{CaCl}_{2}$. All precipitations were carried out at $3^{\circ}$.

Fat. Perinephric fat was extracted with hot ethanol, the extract was dissolved in ether and impurities were precipitated with acetone. The fat was dried over $\mathrm{CaCl}_{2}$ in vacuo.

Glycogen. Glycogen was prepared from cow liver using the method of Bell \& Young (1934). Repeated precipitations of the glycogen with ethanol were employed.

Phospholipins. Two preparations were made from the brains of two cows. The first method employed extraction with hot ethanol, and the other the chloroformmethanol extraction described by Folch, Ascoli, Lees, Meath \& le Baron (195I). The crude extracts were purified by repeated precipitation from ether with acetone, and finally dried in vacuo over $\mathrm{CaCl}_{2}$. The preparation was thought to be largely lecithins with some slight admixture of cephalins.

\section{RESULTS}

The analyses of the tissues are expressed on an ash-free basis, and are given in Table 2. From the carbon and nitrogen content of the tissues the calorific value was calculated using Armsby's (1917) factors, with the results presented in Fig. I. In Table 3 the mean calculated values have been compared with the mean observed values. It will be noted that Armsby's factors gave a significant overestimation of the calorific value of muscle tissue. This may be due to several causes. The fat and protein present in the sample may have had on average a lower calorific value than the preparations used by Armsby (1917) as the basis for the derivation of his factors. 
Table 2. Elementary analyses and calorific values of bovine tissues, expressed on a dry, ash-free basis

\begin{tabular}{|c|c|c|c|c|}
\hline Sample no. & Tissue & Carbon $(\%)$ & Nitrogen $(\%)$ & Cal. $/ \mathrm{kg}$ \\
\hline I & \multirow[t]{9}{*}{ Muscle } & $55 \cdot 52$ & 14.05 & $5^{876}$ \\
\hline 2 & & $53 \cdot 62$ & 15.42 & 5659 \\
\hline 3 & & $55 \cdot 30$ & 13.80 & 5823 \\
\hline 4 & & $52 \cdot 24$ & $15 \cdot 10$ & 5731 \\
\hline 5 & & $57 \cdot 47$ & I1.36 & 6539 \\
\hline 6 & & $53 \cdot 69$ & $14 \cdot 32$ & 5745 \\
\hline 7 & & 53.77 & $14 \cdot 60$ & 5944 \\
\hline 8 & & $53 \cdot 3^{8}$ & $14 \cdot 02$ & 5791 \\
\hline 9 & & $53 \cdot 36$ & 14.70 & 5796 \\
\hline IO & \multirow[t]{5}{*}{ Brain } & $6 r \cdot 83$ & $9 \cdot 08$ & 7244 \\
\hline I I & & $63.5 \mathrm{I}$ & $7 \cdot 88$ & 7221 \\
\hline 12 & & $6 x \cdot 24$ & $8 \cdot 4 x$ & 7434 \\
\hline 13 & & $62 \cdot 59$ & $9 \cdot 22$ & 7202 \\
\hline 14 & & 63.96 & $9 \cdot 45$ & 7064 \\
\hline I5 & \multirow[t]{5}{*}{ Liver } & 56.00 & $12 \cdot 8 I$ & 6069 \\
\hline 16 & & 55.44 & $11 \cdot 46$ & 6374 \\
\hline 17 & & $55 \cdot 23$ & $11 \cdot 17$ & 632 \\
\hline 18 & & $57 \cdot 58$ & 9.73 & 6048 \\
\hline 19 & & $57 \cdot 63$ & II $8 \mathrm{I}$ & 609 \\
\hline 20 & \multirow[t]{5}{*}{ Fat } & $74 \cdot 66$ & 0.27 & 932 \\
\hline 21 & & 74.99 & 0.71 & 917 \\
\hline 22 & & Samples & 0.13 & 946 \\
\hline $\mathbf{2 3}$ & & deteriorated & 0.08 & 9383 \\
\hline 24 & & before analysis & 0.07 & 941 \\
\hline
\end{tabular}

Table 3. Prediction of calorific value of tissues from their carbon and nitrogen content, using Armsby's (1917) factors

\begin{tabular}{|c|c|c|c|}
\hline Tissue & $\begin{array}{l}\text { Observed } \\
\text { value } \\
A \\
(\mathrm{Cal} / \mathrm{kg})\end{array}$ & $\begin{array}{c}\text { Calculated } \\
\text { value } \\
\text { B } \\
\text { (Cal. } / \mathrm{kg} \text { ) }\end{array}$ & $\begin{array}{l}(B-A) \text { with } \\
\text { standard error } \\
(\text { Cal./kg) }\end{array}$ \\
\hline Muscle & $5878 \cdot 2$ & 6010.9 & $132.7 \pm 43.9^{*}$ \\
\hline Brain & $7229^{\circ} 0$ & $7332 \cdot 6$ & $103 \cdot 6 \pm 113 \cdot 0$ \\
\hline Liver & 6183.2 & 6413.2 & $230 \cdot 0 \pm 135 \cdot 2$ \\
\hline Fat & 9250.0 & $9254^{\circ} 5$ & $4 \cdot 5 \pm 57 \cdot 1$ \\
\hline All tissues & & & $136 \cdot 7 \pm 45 \cdot 3^{* * *}$ \\
\hline
\end{tabular}

The overestimation may also have arisen from the presence of nitrogen-free material (e.g. glycogen) with a calorific value lower than that of triglyceride fat. Alternatively the error may have been due to non-protein nitrogenous material, the calorific value of which was overestimated by the arbitrary division into 'protein' and 'fat'. With brain, rich in phospholipins and liver rich in glycogen, there was not, however, any significant overestimation of calorific value.

In Table 4 calorific values of various purified tissue components are presented. The wide variation in the calorific value of human body fat has already been referred to but the single value for depot fat of cattle is in fair agreement with the value quoted by Armsby. The calorific value of purified myosin was higher than that given by Armsby, for muscle protein, as summarized in Table I, but its nitrogen content was decidedly lower than the conventional one of $16 \%$. 


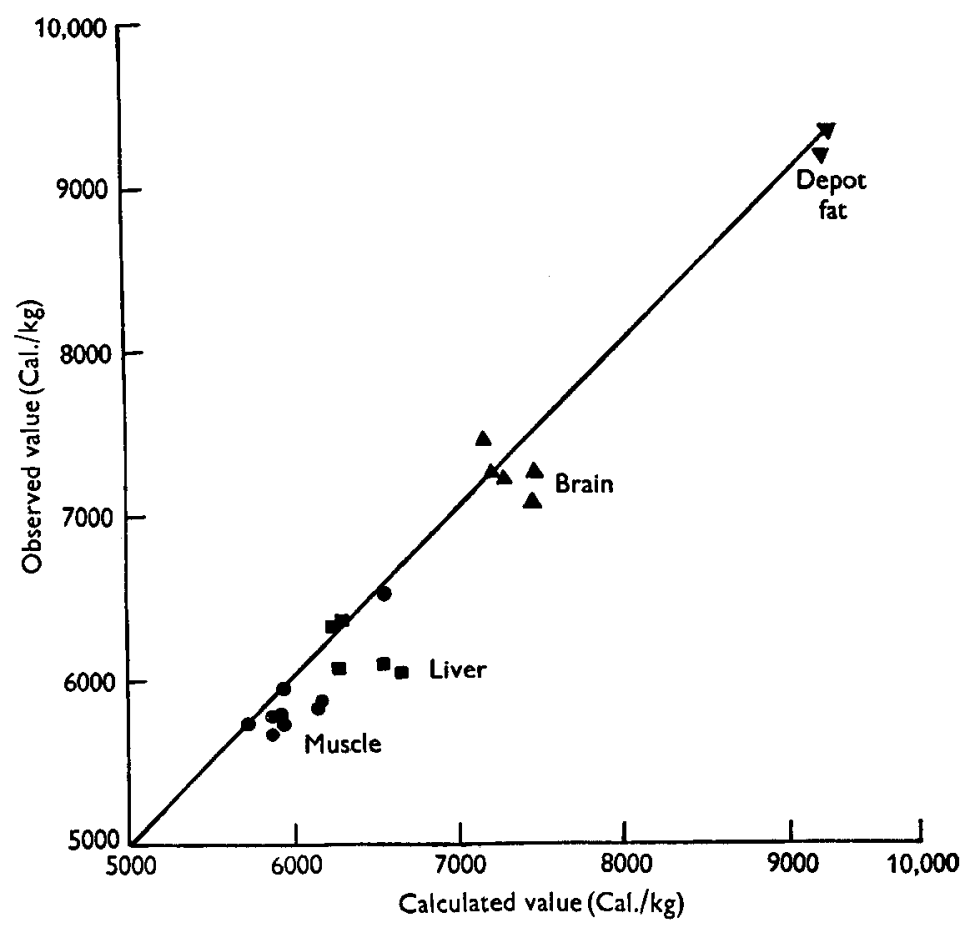

Fig. I. The accuracy of prediction of the calorific values of tissues of cattle from their carbon and nitrogen content using Armsby's (1917) factors.

Table 4. Elementary analyses and calorific values of purified tissue constituents expressed on a dry, ash-free basis

\begin{tabular}{|c|c|c|c|}
\hline $\begin{array}{c}\text { Tissue } \\
\text { constituent }\end{array}$ & $\begin{array}{c}\text { Nitrogen } \\
(\%)\end{array}$ & $\begin{array}{c}\text { Carbon } \\
(\%)\end{array}$ & Cal. $/ \mathrm{kg}$ \\
\hline Fat (depot) & 0.00 & $76 \cdot 51$ & 9398 \\
\hline Glycogen & $1 \cdot 70$ & $45 \cdot 27$ & 4117 \\
\hline Phospholipin I & $\begin{array}{l}\mathbf{I} \cdot 97 \\
\mathbf{I} \cdot 97\end{array}$ & $\overline{62 \cdot 90}$ & $\begin{array}{l}7866 \\
8137\end{array}$ \\
\hline Myosin & 15.50 & $57 \cdot 05$ & 5949 \\
\hline
\end{tabular}

The values for glycogen and for the mixed phospholipins of brain are, to our knowledge, the only published observations on the calorific value of these substances. The values are shown in Fig. 2 together with limited analytical data on other purified tissue components as summarized by Fries (1907). The values for non-protein nitrogen-containing substances are all above the line that relates the calorific value of tissues solely to their fat and protein content according to the Armsby factors. The values for phospholipin, for glycogen and for succinic acid lie below the line. The deviation of phospholipin is small, and the error introduced by nitrogenous extractives would be in the reverse direction to that noted in Table 3 . It may be concluded, therefore, that the presence of glycogen and of other carbohydrate derivatives probably accounts for the major part of the discrepancy. In any event, Fig. 3 suggests that the discrepancy that arises from the application of Armsby's factors to analytical data for whole tissues is due to the assumption that nitrogen 


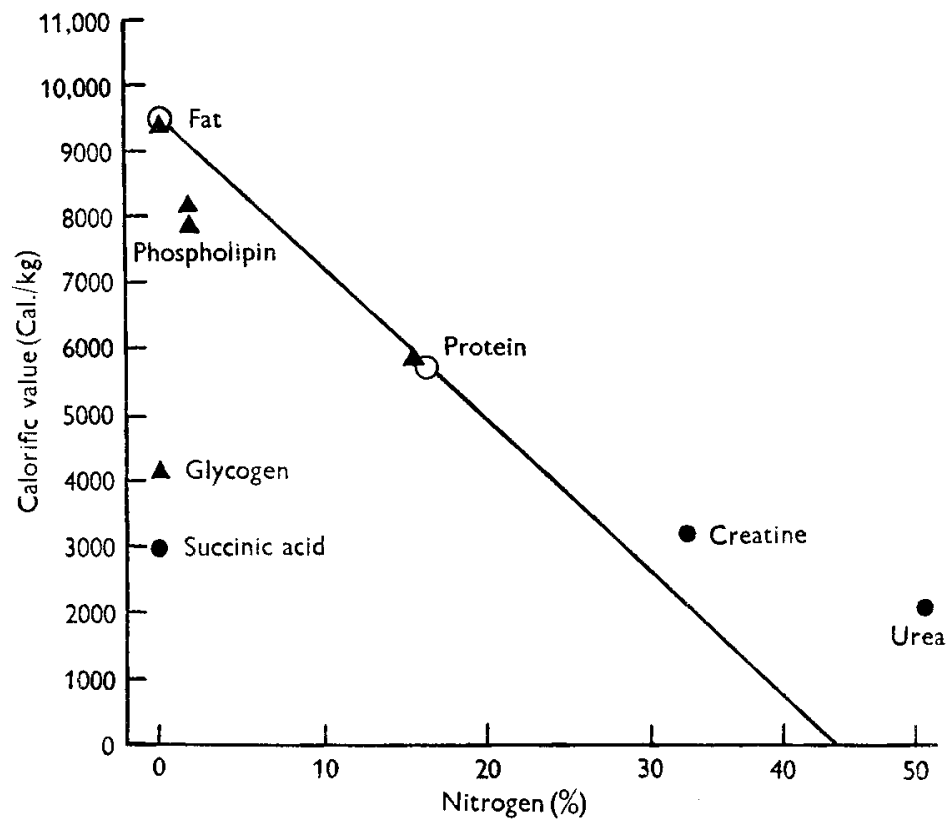

Fig. 2. The calorific values of constituents of pure tissues of cattle in relation to their nitrogen content. $\mathrm{O}-\mathrm{O}$, values of Armsby (1917); $\boldsymbol{\theta}$, values of Fries (1907); $\boldsymbol{\Delta}$, values obtained in present work.

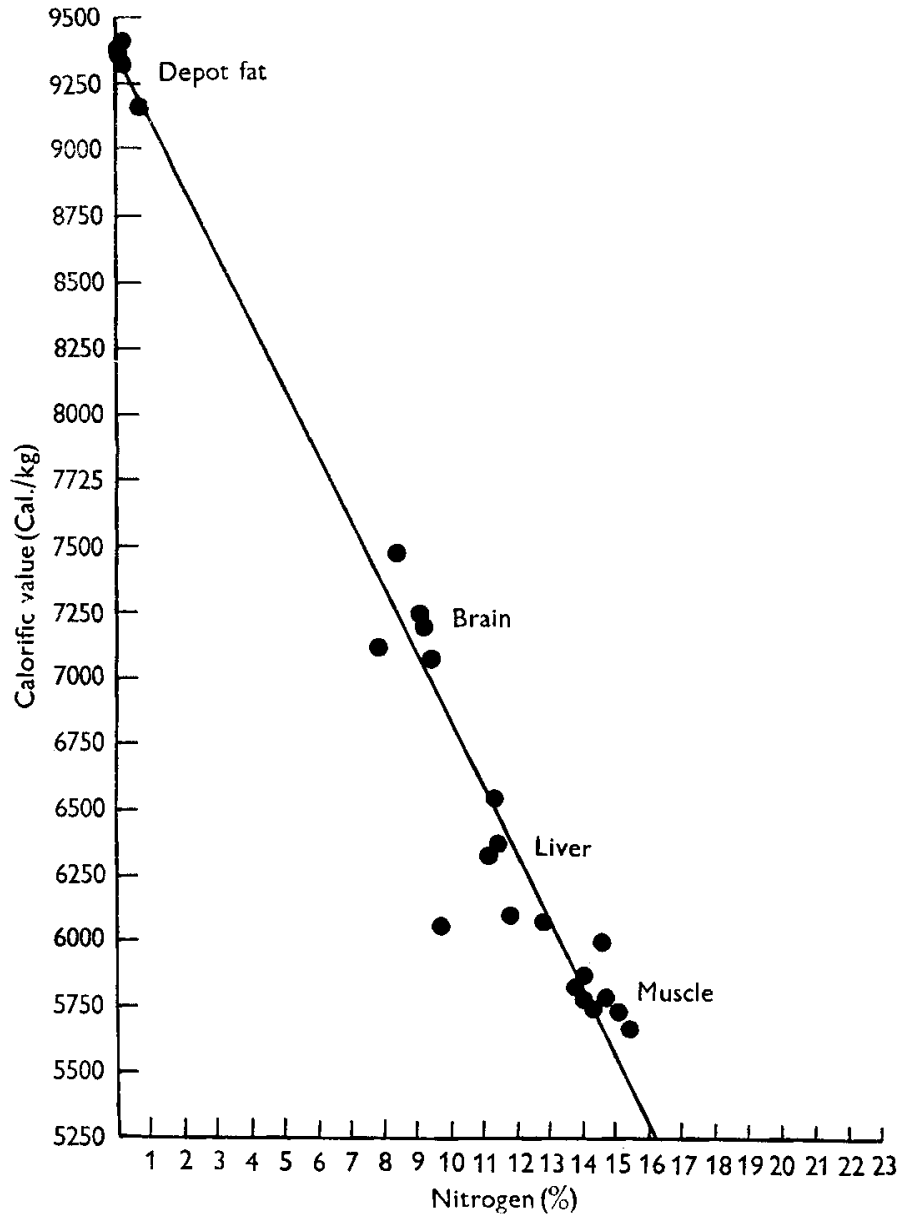

Fig. 3. The relation between the calorific values of dry, ash-free tissues of cattle and their nitrogen content. 
retention represents retention of a mixture of purified protein and triglyceride fat, rather than of a highly complex system of nitrogen-containing and nitrogen-free substances.

To make allowance for the discrepancies that arise from Armsby's assumptions, an empirical approach was adopted. The calorific value of materials containing no nitrogen and containing $16.0 \%$ nitrogen was evaluated by statistical analysis of the data in Table 2. The calorific value of the ash-free dry matter of the tissues was related to their nitrogen content and the results are shown graphically in Fig. 3 .

The equation was:

$$
\mathrm{Cal} .=9367-252 \cdot 9 \mathrm{~N} \text {, }
$$

where $\mathrm{Cal} .=$ Calories $/ \mathrm{kg}$ dry, ash-free tissue and $\mathrm{N}=$ the nitrogen content expressed as a percentage.

The regression was very highly significant $(P<0.001)$. From the equation it may be calculated that a tissue containing no nitrogen had a calorific value of $9367 \mathrm{Cal} . / \mathrm{kg}$ and one containing $16 \%$ nitrogen, of $5322 \mathrm{Cal} . / \mathrm{kg}$.

These two values are lower than the values of $9500 \mathrm{Cal} / \mathrm{kg}$ for fat and $5700 \mathrm{Cal} / \mathrm{kg}$ for protein, used by Armsby. With fat, as might be inferred from Table 2, the difference was small $\left(\mathrm{I}^{\circ} 4 \%\right)$ but with protein the difference was $6 \cdot 6 \%$, far too large to be accounted for by any analytical discrepancy. Though this value for protein disagrees with those given in Table I, it agrees with a figure of $5345 \mathrm{Cal} / \mathrm{kg}$ given by Rubner (quoted by Lusk, I93I). This was an analysis of beef muscle that had not been subjected to any purification.

A similar statistical analysis was made of the relationship between the nitrogen and the carbon content of the tissues. This was also very highly significant statistically, and the equation was

$$
\mathrm{C}=74 \cdot 84-\mathrm{I} \cdot 478 \mathrm{~N} \text {, }
$$

where $\mathrm{C}=$ the carbon content in the ash-free dry matter and $\mathrm{N}=$ the nitrogen content, both expressed as percentages.

From this equation a conventional fat would be expected to contain $74.84 \%$ carbon, and a conventional protein with $16 \%$ nitrogen would contain $51 \cdot 2 \%$. The carbon content of protein containing $16 \%$ nitrogen is decidedly lower than might be expected from the results summarized in Table I, which were obtained by earlier workers using extracted muscles carefully freed of chemical fat, and the value obtained for myosin in the present studies.

\section{DISCUSSION}

The use of balances of carbon and of nitrogen to estimate calorie retention is clearly limited if the material retained is regarded solely as purified protein and fat. The error is small but systematic. Attempts to determine the storage of materials more exactly by simultaneous estimation of retention of hydrogen, of carbon and of nitrogen are possible (Atwater \& Benedict, 1904), but it is doubtful whether the additional expenditure of time is adequately compensated by an increased precision.

An alternative approach is to abandon purified protein as a base-line and to substitute for it a statistical base-line representing the mean carbon content and calorific value of that mixed deposited material that has a nitrogen content of $16 \%$. This will include the glycogen, phospholipin, nitrogenous extractives and other 
organic compounds that are deposited along with protein when an animal retains nitrogen. This process assumes that such a deposition is of constant composition, which is certainly not correct. The same criticism is true of other factors used in carbon and nitrogen balance methods, and an empirical measure using material obtained from animals in a normal state of nutrition may possibly minimize this error in practical experiments.

It may be suggested therefore that the factors summarized in Table 5 should be used for the computation of the results of carbon and nitrogen balances rather than those of Armsby.

Table 5. Suggested factors for the computation of the calorie storage from carbon and nitrogen balances

\begin{tabular}{|c|c|c|}
\hline \multirow[b]{2}{*}{ Computation* } & \multicolumn{2}{|c|}{ Multiplication factors } \\
\hline & $\begin{array}{c}\text { Armsby's (1917) } \\
\text { original }\end{array}$ & Suggested \\
\hline Protein stored from nitrogen retention & $6 \cdot 25$ & $6 \cdot 25$ \\
\hline Calories stored as protein from protein stored (Cal. $/ \mathrm{kg})$ & 5700 & 5322 \\
\hline Carbon content of protein from protein $(\mathrm{g} / \mathrm{g})$ & 0.5254 & $0.5120 \dagger$ \\
\hline Fat retention from retention of non-protein carbon & $\frac{100}{76 \cdot 5}=1 \cdot 31$ & $\frac{100}{74 \cdot 84 \dagger}=1 \cdot 34$ \\
\hline Calories stored as fat from fat retention (Cal. $/ \mathrm{kg}$ ) & 9500 & 9367 \\
\hline
\end{tabular}

* In practice it is not necessary to compute protein retention or fat retention, the factors being combined and expressed in terms of nitrogen and carbon retentions alone. The full stages are given here for simplicity.

+ See p. 89 .

SUMMARY

1. The calorific value and carbon and nitrogen content of the tissues of cattle have been determined.

2. Factors normally used for the prediction of calorific value from the carbon and nitrogen content of tissues have been examined and have been shown to cause a small systematic error.

3. Analyses of purified fat and protein agree with those on which these factors were based.

4. It is pointed out that the error arises from the assumption that pure protein and triglyceride fat are the only materials stored by the animal during growth or fattening. The error can be reduced by using as a base-line a statistical estimate of the carbon content and calorific value of a tissue containing $16 \%$ nitrogen.

5. Supporting evidence is adduced from analyses of purified tissue constituents and a set of factors is suggested.

\section{REFERENCES}

Argutinsky, P. (1894). Pflüg. Arch. ges. Physiol. 55, 345.

Armsby, H. P. (1917). The Nutrition of Farm Animals. New York: The Macmillan Co.

Atwater, W. O. (1895). Bull. U.S. Off. Exp. Stas. no. 21.

Atwater, W. O. \& Benedict, F. G. (1904). Publ. Carneg. Instn. no. 42.

Beakley, W. R. (195 r). F. sci. Instrum. 28, 176.

Bell, D. J. \& Young, F. G. (1934). Biochem. F. 28, 882.

Cathcart, E. P. \& Cuthbertson, D. P. (193I). F. Physiol. 72, 349. 
Cuthbertson, D. P. (1933). Biochem. F. 27, 1099.

Edsall, J. T. (1930). F. biol. Chem. 89, 289.

Folch, J., Ascoli, I., Lees, M., Meath, J. A. \& le Baron, F. N. (1951). F. biol. Chem. 19r, 833.

Fries, J. A. (1907). Bull. U.S. Bur. Anim. Ind. no. 94.

Köhler, A. (1900-I). Hoppe-Seyl. Z. 31, 479.

Lusk, G. (1931). The Elements of the Science of Nutrition. Philadelphia: W. B. Saunders Co.

Pregl, F. (r924). Quantitative Organic Micro-analysis. London: J. and A. Churchill.

Rubner, M. (1885). Z. Biol. 21, 312.

Schulze, E. \& Reineke, A. (1867). Landw. VersSta. 9, 97.

Stohmann \& Langbein (1891). F. prakt. Chem. (N.F.) 44, 364 (quoted by Armsby, 1917).

\title{
The Cholinesterase Problem in the Newborn Puppy
}

\author{
By R. A. McCANCE AND L. M. BROWN \\ Medical Research Council Department of Experimental Medicine, \\ University of Cambridge
}

(Received 2 February 1952)

McCance, Hutchinson, Dean \& Jones (I949) showed that the pseudo-cholinesterase activity in the serum of the puppy might increase up to twenty-five times its initial value in the first 3 days of life, and decrease again within about ro days. The massive rise was attributed to the absorption of intact molecules of enzyme through the intestinal wall from the mother's colostrum, which exhibited a very high cholinesterase activity. The present study was undertaken $(a)$ to provide some information about the rate of destruction of the colostrum cholinesterase by digestive enzymes of the puppy, adult dog and pig in vitro; and $(b)$ to find out whether the cholinesterase in the serum was taken up by any of the puppy's tissues, thus giving a clue to its function.

\section{METHODS \\ Animals}

Organs from adult dogs that had been killed for experimental purposes in other Departments were obtained immediately after death. Since neither the serum nor the red cells showed any change in cholinesterase activity as a result of these experiments, it is unlikely that the activity of the organs was altered. Fresh pig pancreas and duodenum were obtained from the local slaughterhouse.

Most of the puppies were born in the Department. They were weighed, killed by a blow on the head, decapitated and bled into a centrifuge tube. The organs were removed and prepared for cholinesterase estimations, and samples of pancreas were also taken for preparation of proteolytic enzymes and histological examination.

\section{Digestion experiments}

Preparation of proteolytic enzymes. Pancreas from pigs, adult dogs and newborn puppies was minced or cut up finely with scissors, washed with acetone and ether, allowed to dry at room temperature and then sieved and stored. To obtain enterokinase, the mucosa was scraped from the wall of the duodenum and dried, sieved and stored in the same way as the pancreas. A mixture of intestinal ereptic enzymes was obtained 